\title{
THE NEED FOR ISLAMIC BANKING SERVICES IN COMMERCIAL BANKS OF UZBEKISTAN AND ITS POSITIVE IMPACT ON ECONOMIC GROWTH
}

\author{
Tursunov Anvar Sultanovich \\ Lecturer in the department of \\ "Budget Accounting and Treasury, \\ Tashkent Institute of Finance \\ Mail:anvartursunov7@gmail.com
}

ABSTRACT

This article presents the development of Islamic banking services, development trends in the World Bank financial system and the factors influencing the growth of the country's economy. Today, two-thirds of Islamic finance is concentrated in Islamic banks. The urgency of establishing Islamic banking services in commercial banks is highlighted. There are practical suggestions and recommendations for the development of this area.

Keywords: Islamic economy, Islamic banking, commercial bank, Islamic window, interest (ribo), zakat (property tax)

\section{INTRODUCTION}

The Islamic banking system remains one of the fastest growing industries in the world today and includes innovative financing mechanisms. The issue of implementing the Islamic banking system is one of the issues that have been awaited by our entrepreneurs for many years. In recent years, the total assets of Islamic financial institutions have reached \$ 2.5 trillion, growing at a rate of 15 to 20 percent per year. [2] Therefore, it is important to attract funds from existing banks, investment funds and companies based on Islamic finance in developed countries to support the socioeconomic development of Uzbekistan and the private sector.

Islamic banks are a bank or a system of banking activities that implements banking services in practice in accordance with the principles of Sharia (Islamic rules). Principles that value moral values in all dealings have a special appeal. The Shari'a prohibits the giving or receiving of money, as well as the payment or acceptance of interest payments for trade and other activities that provide goods or services that are considered to be contrary to its principles. Although in the past these principles were used as the basis of a prosperous economy, in the late twentieth century, a number of Islamic banks were formed to provide an alternative basis for Muslims, which in turn provided Islamic banking services not only to Muslims but also to the nation's religious affiliation. The smell was all you could use.

\section{LITERATURE REVIEW}

The term "Islamic economics" was first used in the 1947 book "Islamic Economics" by the Indian Muslim scholar Sayyid Manazir Gilani in Urdu. According to Saudi economist Muhammad Omar Chapra, Islamic economics is a network of knowledge that helps to achieve human well-being through the distribution of unique resources in accordance with Islamic teachings, ensuring the inviolability of individual freedoms and macroeconomic and environmental incompatibility. that is, waste is not allowed. [1]

The authors of many well-known works on Islamic banking services and its specific aspects are the eminent jurists Yusuf Qarzawi and Taqi Osmani. [2] In 2013, German scholar Alexander Walters wrote a monograph on Islamic finance strategies, institutions, and first experiments in Central Asia. The paper argues that Uzbekistan, located in the heart of Central Asia, is a closed country and that Islamic finance has not yet developed, and that it could be a source of opportunities and a center for Islamic finance in Kazakhstan. [8] Baidaulet Yerlan, one of the leading scholars in Central Asia, wrote his book, Fundamentals of Islamic Finance, in 2014. The play illustrates the development of Islamic services in Central Asia on the example of Kazakhstan.

Islamic banking services in commercial banks operate according to certain rules. This set of laws is defined by the Shari'a and consists of the following four sources. The first is the Holy Qur'an, which is the original and unchanging source of religious knowledge. The Qur'an contains the revelations of Allah conveyed to the Prophet Muhammad through Gabriel and is a divine instruction addressed to all mankind.

The second source of these laws is the hadiths. They consist of the sunnahs, sayings, instructions, and repetitions of our Prophet Muhammad (peace and blessings of Allaah be upon him). Of course, the hadiths are very important in understanding the first source, the Qur'an.

The third source that forms the Shari'ah law is called Ijma. Ijma are solutions developed for a matter or situation by well-known Islamic scholars who are known and recognized by the Muslims of the community. In Islamic law, scholars who have knowledge at the level of independent judgment from the Qur'an and the Sunnah are called Mujtahids.

The fourth source is called analogy. The term refers to a "measurement" or comparison of two similar phenomena. Qiyas is a fatwa (solution) issued by mujtahid scholars on the basis of the Qur'an and hadiths on complex, controversial new issues. For example, a new issue has arisen in the lives of Muslims. This issue is not mentioned in the Qur'an or the Sunnah, but there is another similar issue. Scholars judge by comparing the issue with the new issue. [7] 


\section{ANALYSIS AND RESULTS}

In the four years since the onset of the financial crisis, Islamic banking assets have averaged $17 \%$ per year, which is 2 3 times faster than traditional banks. [10] Islamic banking services are radically different from traditional banking. In particular, Islamic law strictly prohibits the collection and accumulation of interest on loans. The income of Muslims should come in an honest and right way. Also, spending money, whether for one's own needs or for the needs of society, must be done in accordance with the Shari'ah. All property belongs to God and is created to be shared between society. Muslims who have reached the nisab should help the poor and needy. This is done through the zakat system, which is one of the pillars of Islam. The emergence of Islamic services dates back to the time of the Prophet Muhammad (peace be upon him). Its further formation as a modern banking is shown in the table below

\section{In 1963, the first Islamic bank was opened in Eygpt}

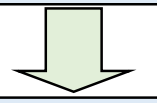

In 1975, the Islamic Bank was established in Dubai

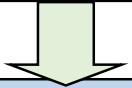

In 1979, an Islamic insurance company was established in Sudan

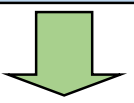

In 1983, Malaysia passed a law on Islamic banking

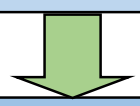

1985-1989 Iran switches to a full-fledged Islamic banking system

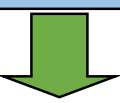

In 1990, a Sharia Council was established under the Islamic Bank in Bahrain

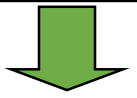

In 2002, Islamic Banking Standards were developed in Malaysia

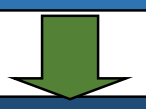

In 2010, an international Islamic financial market was established in Malaysia and Bahrain

Table 1. Stages of development of the Islamic banking and financial system

Source: its compiled independently by the author based on Citybank report,2018

Islamic scholars have developed alternative Islamic banking services from traditional banking services by financing Sharia-compliant contracts. Due to the high demand for Sharia-compliant banking services, many Islamic banks have been established in many regions of the Middle East and Asia, including Malaysia (1963), Bangladesh (1983) and Indonesia (1991). The Islamic Development Bank (ISDB) was established in 1975 as a regional development institution with the aim of promoting the economic development of Muslim countries and financing them in accordance with Sharia law. [1] 
Islamic banking principles provide a balance between extreme capitalism and communism. It offers man the freedom to create and give wealth, while at the same time regulating society with divine guidance that establishes moral rules and norms of conduct that require sincerity of intention rather than man-made rules. When these rules and norms are followed by the people, there will be peace and prosperity for the wider society, and the resources will be distributed fairly among the members of the society.

The theoretical basis of the need for Islamic banking services and their importance in economic growth can be seen in the following criteria:

1. By giving a particular person the right to amass wealth and increase economic well-being, Islamic economics sets the boundaries of halal (permitted) and haram (forbidden or illegal) ways in carrying out such economic activity. Islam broadly prohibits all activities that are economically or socially harmful. Examples include gambling or drug cultivation, drug dealing, and so on.

2. Recognizing the right of a person to own legally acquired property, Islam commands a person to spend his property wisely and to save it, not to waste it, and forbids it to be wasted.

3. While allowing one to keep excess wealth, Islam distributes a portion of the excess income for the benefit of society through the zakat system, to the poor, the needy.

4. Regulates the accumulation and use of natural resources. This system does not allow the wealth of the whole society to be concentrated in the hands of a few people and to be managed only by them. Inheritance and its distribution are also regulated on the basis of established criteria.

5. In general, the economic system envisaged by Islam aims at social justice, which prevents an individual enterprise or entrepreneur from harming not only the community but also the individual himself.

The Islamic banking system contributes to the development of the economy in the following three main directions [15]: the real economy directly conducts monetary operations, that is, it can sell property after gaining ownership. It does not fund businesses that produce products that are harmful to society, such as alcohol, tobacco, casinos, and pornography. At the same time, it provides for the expansion of effective projects, the exchange and sale of real goods and services. The benefits and harms can be seen together. Islamic finance offers a number of specific Islamic banking services that apply the theories outlined above and can be used for economic development.

\section{CONCLUSIONS AND RECOMMENDATIONS}

The Islamic Bank has successfully passed the world experience and is developing rapidly. It is expanding not only in countries with a large Muslim population, but also in other countries with a Muslim minority, such as the United Kingdom or Japan. Similarly, countries such as India, the Kyrgyz Republic and Syria have been licensed to conduct Islamic banking and are working hard to develop the sector. The Covid 19 pandemic has had a significant negative impact on the world economy, including a downturn in our economy. In this situation, the banking and financial sector, which is the backbone of the economy, needs to take the necessary measures to revive the economy

First, it is necessary to amend the current legislation, such as the Law on Banks and Banking, the Law on the Central Bank, the Tax Code, the Civil Code and a number of other by-laws. Based on the experience of Central Asian countries, it is necessary to develop a separate law on the establishment and development of a separate Islamic banking and financial system.

Second, it is necessary to establish Islamic banking services through the establishment of Islamic windows in commercial banks. In this case, it would be expedient to use foreign experience to apply the experience of Malaysia in the implementation of Islamic banking services in Uzbekistan.

Third, it is necessary to establish and develop international cooperation with foreign Islamic banks in the organization of Islamic banking services. Islamic Development Bank,

Dubai Islamic Bank, Maybank Islamic Berhad, ITFC (International Islamic Trade Corporation), Kuwait Finance House are well-known Islamic financing organizations.

Fourth, higher education institutions, including the Tashkent Financial Institute and the Tashkent State University of Economics, should allocate quotas for bachelor's and master's degrees in Islamic banking and finance. The establishment of joint faculties with prestigious international universities is an important step in the training of specialists in this field. At the same time, universities in the United Kingdom, Malaysia and Arab countries are leaders in the field of Islamic banking and finance.

\section{Reference}

1. Ahmad, M. Abu-Alkheil (2012) "Ethical Banking and Finance: A Theoretical and Empirical Framework for the Cross-Country and Inter-bank Analysis of Efficiency, Productivity, and Financial Performance" Ltd. Germany

2. Bekkin R.I., 2009, Islamic economic model and modernity. Marjani Publishers, Moscow

3. Shayx Muhammad Sodiq Muhammad Yusuf. Tafsiri Hilol. Toshkent "Sharq" 2012 5-bet 
4. Mufti Taqi Usmoniy. Al-Azhar Fatwa declaring interest permissible.www.albalagh.net/qa/azhar_fatwa_interest.html.

5. Azmat, S., Skully, M., Brown, K., 2015. Can Islamic banking ever become Islamic? Pac. Basin Financ. J Available at.

6. Chapra M.U What is Islamic Economics?-Jeddah 2001, p-33

7. E.A.Baydaulet, X. Xasanov "Islomiy moliya asoslari” O‘zbekiston 2019, 401-bet

8. Alexander Walters, Islamic Finance in the States of Central Asia: Strategies, Institutions, First Experiences // 2013 - PFH Gottingen.

9. Baidaulet Yerlan. Basics of the ethical Islamic fnance // 2014 - Almaty

10. Citibank annual report 2018, Citi Research, Reuters, SNL Research

11. "O'zbekiston Respublikasini yanada rivojlantirish bo'yicha harakatlar strategiyasi to 'g'risida"gi O'zbekiston Respublikasi Prezidentining 2017- yil 7 -fevraldagi PF-4947-sonli Farmoni.

12. www.cbu.uz (O`zbekiston Respublikasining Markaziy banki rasmiy websayti)

13. www.islom.uz

14. http://linkinghub.elsevier.com/retrieve/pii/

15. Ilkhomovich, S. E. (2020). The development of electronic trade and its role in general trade activities. ACADEMICIA: An International Multidisciplinary Research Journal, 10(3), 128-132.

16. Xidirberdiyevich, A. E., Ilkhomovich, S. E., Azizbek, K., \& Dostonbek, R. (2020). Investment activities of insurance companies: The role of insurance companies in the financial market. Journal of Advanced Research in Dynamical and Control Systems, 12(6), 719-725. 